\title{
sciendo
}

DOI 10.2478/sbe-2020-0004

SBE no. 15(1) 2020

\section{NEW MARKETING TENDENCIES IN THE ROMANIAN WINE INDUSTRY}

\author{
FUCIU MIRCEA \\ Lucian Blaga University of Sibiu, Romania
}

\begin{abstract}
:
In the last decade or so, the Romanian wine industry has changed and developed greatly, by the increase of wine producers, especially the niche producers, alongside the traditional, big, producers. The paper aims to understand the new tendencies in the field of marketing, that occur on the wine industry of Romania, as well as the changes that take place in the minds and lives of the consumers in the context of the online world, combined with new trends and technologies that can be used by the consumers. Secondly, the paper represents a secondary data analysis of the International and Romanian Wine Industry, in terms of production and consumption, we also presented a short profile of the Romanian wine consumer, as a result of a survey developed by wine industry organisation. The paper shows some new trends of the wine industry, underlined by the specialists, as well as technologies and methods of marketing interaction with the consumers used by the Romanian producers of this product.
\end{abstract}

Key words: marketing, trends, wine industry, consumers, technology

\section{Introduction}

The wine industry in Romania has changed greatly in the last two decades, new brands have come to life, changes have occurred in the wine consumer behaviour of the Romanian consumer and new marketing methods and techniques have been used to interact and to work with the consumer.

In a world when the online has become an integral part of the marketing process, when sometimes, we communicate more online, than we do in person, the wine industry has adapted to the new market and communication tendencies and has, in the last years, started using the online environment, especially the online social networks, in their communication strategy.

We consider that understanding these new marketing tendencies and assessing the new marketing wine brands that have entered the Romanian market, can give us a better understanding of the consumers' needs and wants in this field, can help the wine industry better target their clients and offer a better product or a service. 


\section{Marketing trends in the context of the online business world}

We as individuals and as a society are living in a new and different world than our parents or grandparents did 30 or 40 years ago. Due to the changes that have occurred in the last two decades, with the rise of the online communication, in the late 90's the world has shifted from a face to face or TV based marketing communication process to an online / virtual communication process for especially the great majority of young individuals. The internet, which brought connectivity and transparency to our lives, has been largely responsible for these changes (Kotler at. al. 2017, p.5).

Of course over the years the shift has been caused by changes in the consumer behaviour, were, in the previous years, the individuals were targeted by classical advertising campaigns, today the buying behaviour is influenced by the online, by reviews, by influencers or even random conversation with product / service users.

The social factors that the individuals are influenced by, like the groups and social networks, family and social status are as much of an influence as the influence generated by factors like culture and subculture. The online platforms allow the companies to specifically target subcultures like Hispanic, American, African American or Asian in their marketing strategies (Kotler et. al. 2018, p. 159).

If we consider a comparison of the pre-Internet age and the path of the consumers in the online connected world, we can see several new tendencies and actions that they undertake.

\section{Pre-Internet path of the consumer}
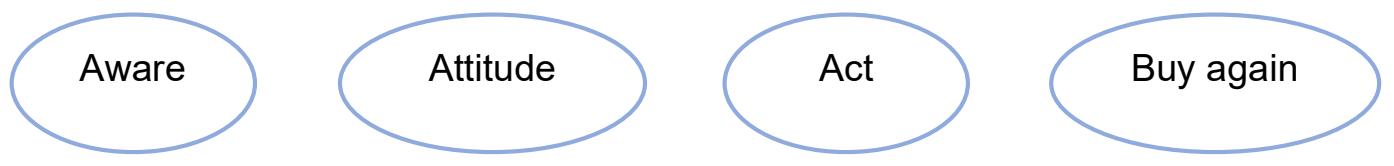

Path of the consumer in a connected world
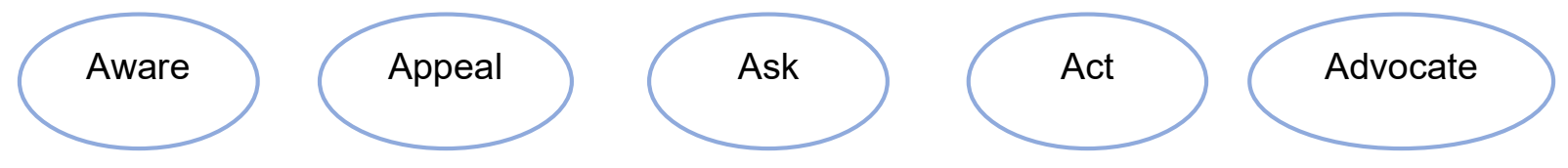

Figure 1: Changes in consumer behavior in an interconnected world

(Kotler, P., Kartajaya, H., Setiawan, I., (2017), Marketing 4.0-moving from traditional to digital, John Wiley \& Sons, Inc., Hoboken, New Jersey, p. 62)

If we look at both perspectives presented in figure 1, we can observe the changes that have occurred in the lives of the consumers and their buying behaviour in the online environment. We can see that in an interconnected world, the consumer uses the online to define his or her's attitude towards a certain product or a service, by the influence of the online community (appeal and ask).

A second change has occurred with the willingness of the consumer to advocate a certain product, service or a brand by showing their loyalty towards it. And last but not least, the third change occurs when deciding about a certain product, service or brand, when the consumer of the digital world has the opportunity to search for multitude of 
information related to the acquisition, he / she can ask previous users, see reviews and make an informed decision before acting on an acquisition.

All these aspects have led the companies to adopt new technologies and marketing strategies that are more up to date with the buying environment that we live in today. Among the most important online marketing trends that we can identify in 2020, we underline (Nidhi, 2020, online):

- Artificial intelligence - is seems that this online tool can be considered the next "big" thing, due to the wide spread of it, in the last year or so. We have robots or programs that can conduct music, are involved in the production process or manage activities like content creation, e-mail personalization, e-commerce transactions etc.

- Programatic Advertising - relates to using artificial intelligence, used by social media platforms and other similar platforms, to better target a specific audience. This method of advertising leads to fast paced and higher consumer conversions.

- Usage of Chatbots - using Artificial intelligence based instant messaging in real time, be it day or night.

- Usage of conversational marketing - a one-to-one, online and real time, consumer-business interaction.

- Personalised message and content - using the online, the social media platforms and other similar online tools, the consumers can be better targeted, with products, services or brands that they like, need or desire. Most of the online users hate general advertising, they want tailored advertising, that they can relate with.

- Using visual marketing - using videos or short demonstrative films can be extremely beneficial for your company and can increase client retention and repurchase. When the consumers are shifting more and more towards online buying, they can not touch, feel the product, therefore the company must find ways of presenting the product and what it does, not just trough pictures, but by showing demonstrative movies.

- Influencer marketing - this word-of-mouth method of reaching the clients or consumers with your product or your brand has become more and more important in the last year. The usage of well-known individuals, famous people can lead to an increase of sales, traffic, views, shares of your online content.

Furthermore, other authors like Rust (2019), Katone et. al. (2019), underline several other aspect and marketing trends that the business world in working towards. Of those we can point out:

- The usage of the 5 D's: digital devices, digital platforms, digital media, digital data and digital technology (Chaffey 2018).

- The usage of the Internet of things - the technologies that communicate with each other, with the producers etc. At the same time, in this context, these technologies can be seen, as both consumers and service providers.

- The Internet of brains - hooking up the human brain to the Internet through a physical connection (Wits University, 2017). An Internet of Brains would change marketing from focusing on individuals to focusing on-the-whole, with the probable implication being that marketing becomes more of a "winner take all.". 
As we can see, the trends and tendencies to become more technological oriented when buying a certain good, service or a certain brand, is out there. We are more, fast paced, than ever, we are more online reachable and interconnected, but is this also true for the activities and fields of activities that are relatively traditional? This the question that one must answer, in the case of the developing Romanian wine industry. Can the abovementioned trends, technologies, online marketing tools be used in the wine industry?

\section{Marketing trends and statistics in the Romanian Wine Industry}

The wine industry of Romania is a fast growing one. Right now, Romania is considered, to be the $13^{\text {th }}$ wine producer of the world in a November report of the International organization of Vine and Wine (OIV Report, 2019).

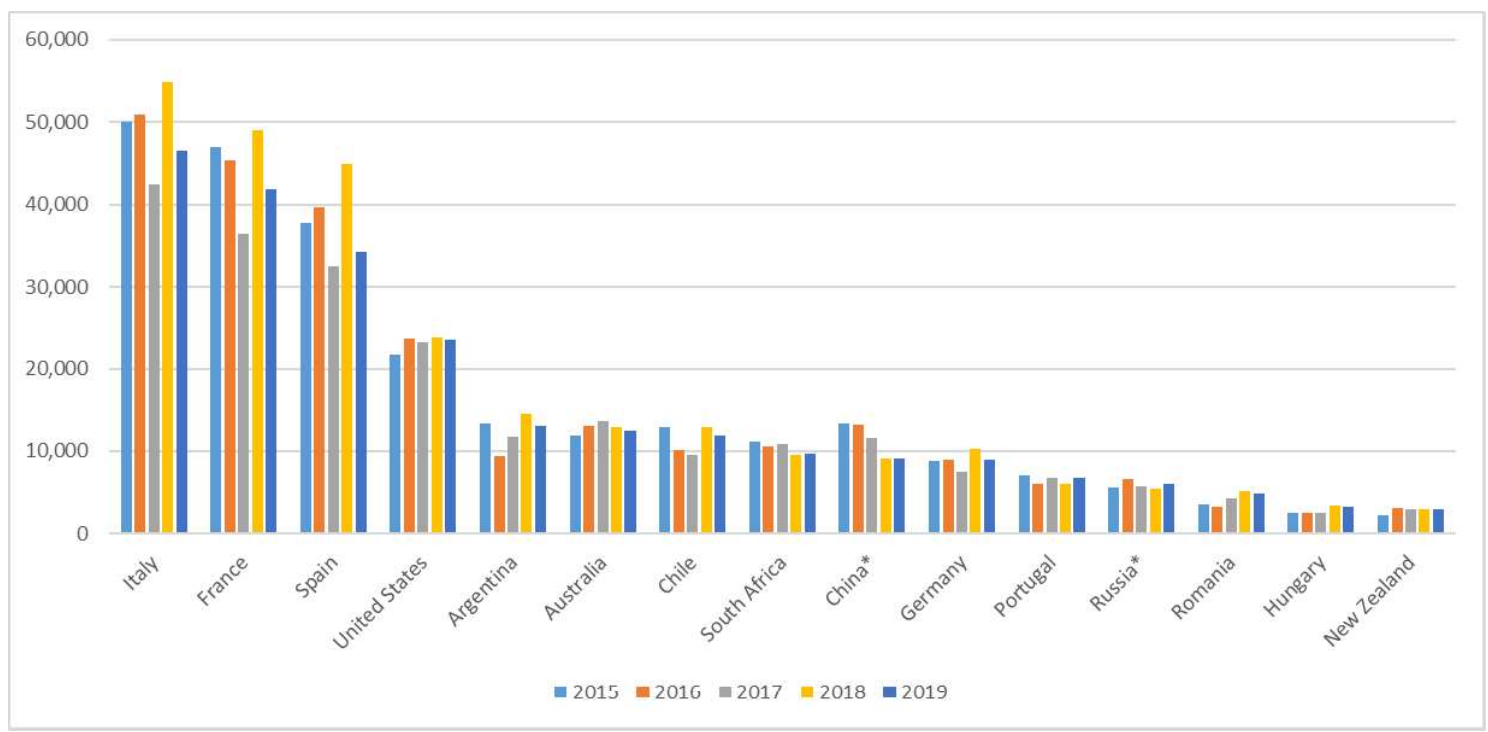

Figure 2: Top 15 Wine producing countries of 2015 - 2019 est.

(OIV Report, https://italianwinecentral.com/top-fifteen-wine-producing-countries/, accessed on February $28^{\text {th }}, 2020$ )

Although the year 2019 is just an estimate, we can observe, across the chart that the year 2019 is estimated to register an average drop of $10 \%$ on the wine production compared to the previous year. As we can see, Italy has a production of 54.8 thousand hectolitres, France has a production of 49 thousand hectolitres, Spain has a production of 44.9 thousand hectolitres, USA 23.9 thousand hectolitres and they represent the four main wine producers of the world, which means $58.70 \%$ of the world total production of wine (294 thousand hectolitres). 


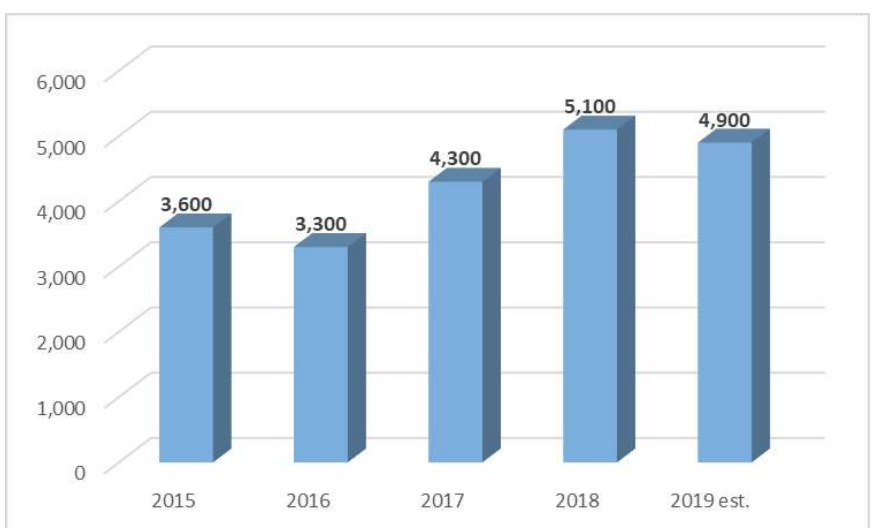

Figure 3: Wine production of Romania 2015 - 2019 est.

(OIV Report, https://italianwinecentral.com/top-fifteen-wine-producing-countries/, accessed on February $28^{\text {th }}, 2020$ )

When we are talking about the Romania, the production of 2018 is at 5100 hectolitres and the estimates for 2019, that the production will be at 4900 hectolitres of wine produces, with a decrease 5\% in comparison with 2018. If we look at the 2015 to 2018 period, we see a constant increase in the wine production in Romania, the 2015/2018 evolution is of $29.41 \%$, with a decrease in 2019 , but that was a general trend at a world level.

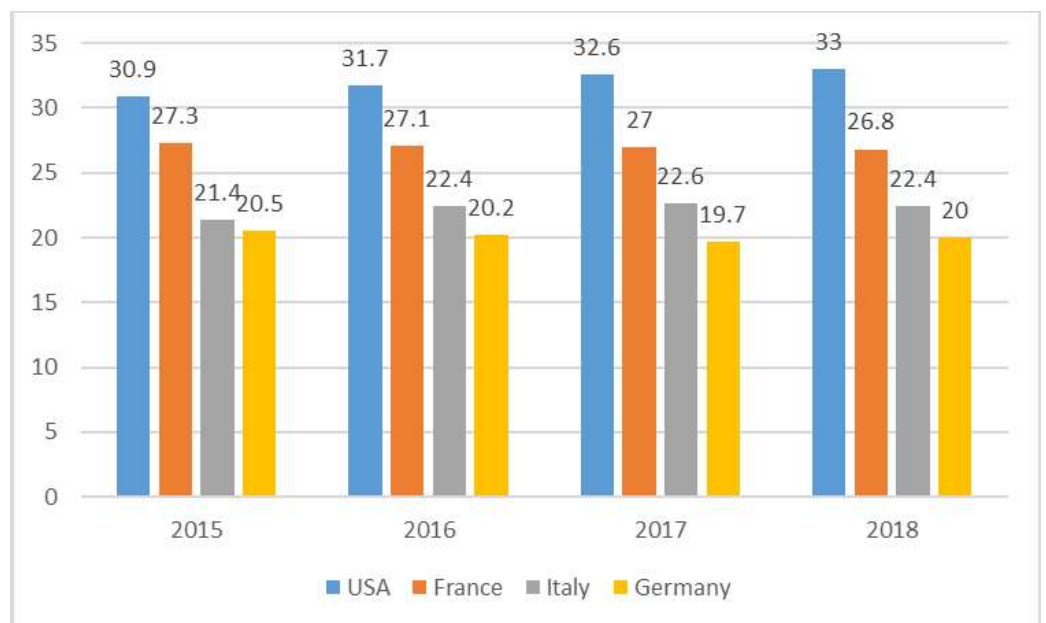

Figure 4: Top 4 wine consumer countries 2015 - 2018 (in million of hectoliters)

(OIV Report, http://www.oiv.int/public/medias/6782/oiv-2019-statistical-report-on-worldvitiviniculture.pdf accessed on February $28^{\text {th }}, 2020$ )

From figure 4, we can see that 3 of the top wine producer countries are also top wine consumers, just that the order is different. We can see that the wine consumption stays relatively the same, with slight variations. For the USA, we can observe an increase from $30.9 \mathrm{mil} \mathrm{hl}$ in 2015 to $33 \mathrm{mil} \mathrm{hl}$ in 2018, an increase of $6.36 \%$, France has a consumption average of $27.05 \mathrm{mil} \mathrm{hl}$, Italy registers a consumption average of $22.20 \mathrm{mil} \mathrm{hl}$. and Germany of 20.1 mil hl. When we talk about Romania, the consumption is at an average of 4.1 million $\mathrm{hl}$ of wine, with an increase from 4 million $\mathrm{hl}$ in 2015 to $4.5 \mathrm{million} \mathrm{hl}$ 
in 2018, and a drop of 3.8 million $\mathrm{hl}$ in 2016 . The 2015 to 2018 increase represents of percentage of $7.31 \%$.

So, this is where we stand in the field of wine production and consumption for the main producing countries and especially for Romania. The next step is to understand the causes for this increase in production and consumption of wine in Romania and what are the main trends of the industry.

According to study developed, in 2019, exclusively online by the CrameRomania.ro \& ReVino.ro on a sample of 2683 people, of which $67 \%$ were male and $33 \%$ were female, with average incomes over 1500 lei, a profile of the Romanian Wine consumers resulted that can show us several important marketing and behavioural trends related to the wine industry in Romania (crameromania.ro, 2019).

Of said profile, we underline several findings that can help in shaping a clear image of the marketing trends of the Romanian Industry:

- The frequency of wine consumption: Several times a week $46.25 \%$; once a week $22.04 \%$ and daily $-22.06 \%$.

- The main vineries that the wines are consumed of: Romanian and International Vineries - 43.54\%; Romanian Vineries - 25.54\%; Homemade wine - 7.95\%.

- Most common used packaging -0.75 I bottle, used by $80.61 \%$ of the consumers.

- Place of acquisition: Grand surface stores (supermarket) - 42.64\%; Specialized shops, vineries of the online $-21.05 \%$; Specialized wine shops $-18.63 \%$.

- Type of wine that is consumed by the Romanian consumer: Red wine - 57,69\%; White wine $-29.37 \%$; Rose wine $-10.74 \%$ and Sparkling wine $-2.21 \%$.

- The great majority $(64.56 \%)$ of the wine consumers are buying dry wine.

- The consumers buy the wine as gifts and for their own consumption.

- The main influence factors of choosing a wine are (multiple choice question): the vinery $(65.8 \%)$, color $(54.9 \%)$, type of grapes $(54.75 \%)$, reasons for consumption $(41.76 \%)$, price $(35.97 \%)$ and producing country $(30.83 \%)$.

- The main information sources about the wines: the internet, specialists and friends that are passionate about the wine.

As we can see from the above presented results of the survey done by CrameRomania.ro \& ReVino.ro in 2019, we can clearly underline several important marketing trends that emerge in the marketing of the Romanian Wine Industry. The Romanian market has a more informed consumer that searches for information before buying a wine. According to the sales manager of the Recaș Vineries, there „a clear realignment of the producer from the idea of quantity towards quality" and "there is a general trend of increasing the consumption of quality wine". (revistaprogresiv.ro, 2019).

At the same time, it seems that the premium brands and products are more and more bought by the Romanian consumers, the premium wines represent a market share of an estimated $30 \%$ of the market as per the 2018 Report of the Purcari Wineries published by BVB Bucharest. In the same financial report, it is stated that the premium brands of Purcari, Ceptura and Bardar have had sales increases of more than $22 \%$ in the year 2018 , compared to the year 2017. As a company, in 2018, the Purcari group has reached a market share of $9 \%$ (Purcari, 2019). 
According to Nielsen reports, there are 5 big wine players in Romania - Cotnari, Vincon, Jidvei, Recaș and Zarea, which represent around $44 \%$ of the wine market of Romania. But the Romanian wine market is shifting by the influx of small wineries that are "flooding" the market with new brands, new types of wines, new labels and new marketing campaigns.

Many of the grand wineries are starting to do a more proactive marketing activities, rather than the traditional marketing activities, but is the small, niche wineries that are the ones that are leading the charge in the process of innovative marketing techniques in the wine industry. Like any other food item, the wine needs to be promoted in a more direct and closer to the consumer as possible. The most common and most important direct marketing activity in the wine industry is the wine tasting, were the consumer interacts with the wine, with the producers / specialists that can offer the most important information related to what is the best way to consume the wine.

Another important aspect is social media presence, and with more than 40 wine producers that have come to life in the last 10 years, social media has become an important tool and environment for promoting ones' wine. Brands like Crama Oprisor, Avincis, Budureasca Cotnari, Liliac or Jidvei have playd big in social media platforms, using Search Engine Optimisation, using Bilingual websites, using easy to use and mobile adapted websites, using blogs and friendly shops (Digital Wine, 2018).

As Facebook is a digital platform that is accessible to anyone with a mobile device, especially a smartphone and the same is for Instagram. In order to be a part of the consumer life, you must be present with daily posts, pictures, responses etc.

Cotnari, one of the biggest wineries of Romania has also one of the largest following on Facebook, with more than 170 thousand and followers is promoting the brand by constantly posting information about the wines, events, images etc. (Faceboo.com, 2020). Among the most important rules of online marketing promoting the wine brands of Romania, we mention (Palasca, 2018): (1) creating a mobile responsive website; (2) link your website to your social media channel; (3) create a blog and permanently update it; (4) create a online wine shop that can bring the consumer closer to you; (5) combine online and offline activities.

Being a rather traditional industry wine making should combine online marketing activities, like social media, email marketing, vloging, Instagram posting, with traditional marketing techniques like wine tasting, wine fairs, sponsoring of certain activities, sales promotion in supermarkets etc.

\section{Conclusions}

We are seeing a world governed by technology, instant communication, mobile devices, interconnectivity of devices, artificial intelligence and many more. But were does an industry, that is rather traditional, stand? The wine industry is adapting to the changes that occur in todays' economy and to the developments that are happening in the lives of the consumers.

From the marketing point of view, we see changes in consumer behaviour, in the decision-making process and in the influence factors. We see a greater interaction with the 
online, we see consumer that inform themselves of products, services brands by searching online, by following influencers, by contribution to vlogs, by reading and contributing to product reviews. At the same time in the paper we presented several new technologies like artificial intelligence, programmatic advertising, usage of chatbots, usage of conversational marketing, personalised message and content that can be used in order to increase the interaction with the consumers and to make them more active in the lives of wine producers.

The second part of the paper, it is presented a secondary data analysis of several statistics about the international wine industry and the Romanian industry. We have for main producers of wine (Italy, France, Spain and USA) that represents more than $50 \%$ of the world production and we have Romania, which is on the $13^{\text {th }}$ place as a wine producer.

Following the statistics of the OIV Report, we underlined a profile of the Romanian wine consumer and we emphasised several important marketing trends and tendencies of the wine market of Romania. We can see that the wine producing companies are using a combination of traditional and modern marketing, they are entering the world of the online by accessing social media and modern marketing tools like blogs, Instagram, Facebook etc.

In conclusion we can state that the Romanian Wine Market is still developing with an additional 40 new wine producers that have entered the market, especially the niche market, with new brands, marketing technologies and methods of interacting with the consumers. We have also seen a change of the profile of the wine consumer towards the online shopping and of information gathering from different online source, as well as an higher interest of the consumer towards the consumption of quality premium wine, rather than on quantity.

\section{References}

Chaffey, D. (2018). What is Digital Marketing? A visual summary, retrieved from https://www.smartinsights.com/digital-marketing-strategy/what-is-digitalmarketing/. in, Kotane et. al. (2019).

Kotane, I., Znotina, D., Hushko, S., (2019), Assessment of trends in the application of digital marketing, PERIODYK NAUKOWY AKADEMII POLONIJNEJ, 33 (2019) nr. 2, DOI: http://dx.doi.org/10.23856/3303

Kotler, P., Armstrong, G., Opresnik M.C., (2018), Principles of Marketing, Pearson Education Limited

Kotler, P., Kartajaya, H., Setiawan, I., (2017), Marketing 4.0 - moving from traditional to digital, John Wiley \& Sons, Inc., Hoboken, New Jersey

Nidhi, D., (2020), Digital Marketing Trends You Can't lgnore in 2020, https://www.singlegrain.com/digital-marketing/digital-marketing-trends-2020/, accessed on February $26^{\text {th }}, 2020$.

Palasca, S., (2018) Digital Wine: Cum se prezintă vinurile românești online?, https://vinul.ro/digitalwine-vinurile-romanesti-online.html, accessed on line on February $29^{\text {th }}, 2020$.

Popescu M., (2019), Ce susține dezvoltarea pieței de vinuri pe axa calitativă?, https://revistaprogresiv.ro/articole/ce-sustine-dezvoltarea-pietei-de-vinuri-pe-axa-calitativa, accessed on line on February $29^{\text {th }}, 2020$. 


\section{Studies in Business and Economics no. 15(1)/2020}

Rust, R., (2019), The future of marketing, International Journal of Research in Marketing, article in press,https://doi.org/10.1016/j.ijresmar.2019.08.002, https://www.sciencedirect.com/science/article/pii/S0167811619300503?via\%3Dihub

Wits University (2017), Biomedical engineers connecting a human brain to the internet in real time, https://medicalxpress.com/news/2017-09-biomedical-human-brain-internet-real.html, accessed on February $27^{\text {th }}, 2020$.

*** OIV 2019 Report on the World Vitiviniculture, https://italianwinecentral.com/resources/factsfigures/, accessed on February 29th, 2020.

*** OIV Report, http://www.oiv.int/public/medias/6782/oiv-2019-statistical-report-on-worldvitiviniculture.pdf, accessed on February $28^{\text {th }}, 2020$

*** Profilul consumatorului român de vinuri în anul 2020, https://www.crameromania.ro/evenimente/profilul-consumatorului-roman-de-vinuri-in-2019443.html, accessed on February $28^{\text {th }}, 2020$.
Purcari
Wineries
Annual
Report,
2018, https://purcari.wine/static/projects/purcari.wine/dist/pdf/Purcari 2018 RO.pdf, accessed on February $29^{\text {th }}, 2020$

*** https://www.facebook.com/cotnari, accessed on February 29 2020. 